\title{
A PROSPECTIVE STUDY TO ANALYZE THE SPECIFICITY OF CHLAMYDIAL HEAT SHOCK PROTEIN (CHSP60) ANTIBODIES TO DIAGNOSE TUBAL INFERTILITY
}

D0I:10.36740/WLek202102102

\author{
Vladyslav 0. Berestoviy' ', Inna V. Sokol', Ahmad A. Mahmood', Valentyna G. Ginzburg' ${ }^{2}$, Dmytro 0. Govsieiev 1,3 \\ 'DEPARTMENT OF OBSTETRICS AND GYNECOLOGY OF POSTGRADUATE DEPARTMENT, BOGOMOLETS NATIONAL MEDICAL UNIVERSITY, KYIV, UKRAINE \\ 2DEPARTMENT OF OBSTETRICS AND GYNECOLOGY №3, BOGOMOLETS NATIONAL MEDICAL UNIVERSITY, KYIV, UKRAINE \\ ${ }^{3}$ DEPARTMENT OF OBSTETRICS AND GYNECOLOGY, KYIV STATE MATERNITY HOSPITAL №5, KYIV, UKRAINE
}

\begin{abstract}
The aim: To investigate the utility of testing for chlamydial heat shock protein 60 (CHSP60) antibodies in the diagnosis of tubal infertility.

Materials and methods: All the collected samples were assayed for lgM and lgG antibodies to chlamydia trachomatis and chlamydial heat shock protein 60 (CHSP60) by using immunofluorescence and enzyme-linked immunosorbent assay (ELISA) techniques, respectively.

Results: There were no substantial differences between antibodies to C. trachomatis in females with tubal infertility (67\%) and non-tubal infertility (48\%). However, women with tubal infertility (45\%) have more anti-CHSP60 antibodies than non-tubal infertility (9\%). Antibody screening for C. trachomatis has only (63\%) sensitivity and (54\%) specificity for detecting tubal infertility. On the other hand, the CHSP60 antibody testing has (44\%) sensitivity and 92\% specificity for diagnosing tubal infertility. A positive microimmunofluorescence (MIF) titer was observed in 12 of 18 (67\%) females with the tubal problem, 31 of 64 (48\%) with non-tubal infertility ( $\mathrm{P}=0.3,0 \mathrm{R}=2.2,95 \% \mathrm{Cl}=0.71$ to 8.01). The CHSP60 antibodies were found in 8 of 18 (45\%) females with tubal problem \& 6 of 64 (9\%) women with non-tubal infertility, power factor alpha a $P=0.004$, $\mathrm{OR}=9.3,95 \% \mathrm{Cl}=2.1$ to 43.2 , power $=1.002$ for $n=0.05)$. Incorporating $\mathrm{CHSP} 60$ and $\mathrm{C}$. trachomatis antibodies testing gives an excellent positive probability proportion of 10 to diagnose C. trachomatis associated tubal infertility.

Conclusions: CHSP60 antibody testing is a more specific evaluation than antibody testing for C. trachomatis for predicting chlamydia-associated tubal infertility. Using these tests at the first infertility examination may help the immediate diagnosis for non-interceptive tubal infertility.
\end{abstract}

KEY WORDS: tubal infertility, tubal occlusion, chlamydial heat shock protein (CHSP60), Chlamydia trachomatis, antibodies

Wiad Lek. 2021;74(2):184-189

\section{INTRODUCTION}

Infection with Chlamydia trachomatis is an important sexually transmitted condition related to tubal infertility with increased salpingitis episodes that leads to tubal blockage [1-3]. Many studies revealed that serologic evidence of previous Chlamydia infection is exceptionally related to tubal infertility [4-8] and also decreased the success rate of a positive outcome for in vitro fertilization (IVF) [9]. The individuals with positive serology to chlamydia are at higher risk of developing the pelvic inflammatory disease (PID) $[10,11]$.

It was suggested that chlamydial antigen might trigger the pro-inflammatory response in host immune cells [12]. The oxidative damage to the DNA and decreased antioxidants concentration may be associated with chlamydia-induced tubal damage [13]. The immunopathology seen in genital tract infections is similar to those elicited by the chlamydial conjunctival infection resulting in scarring trachoma. The reinfection is determined as an essential risk factor in the pathogenesis of trachoma development [14].

The mechanism by which chlamydial infection results in tubal damage have been studied however stays uncertain. Primate research studies recommend that reinfection with C. trachomatis may be the essential part of chronic salpingitis, causing distal tubal blockage [15].

The serological analysis and diagnosis for chlamydial antibodies early point can be a prognostic tool to estimate the risk of CT-related complications and prevent late complication development. Recent research studies have shown a strong association between antibody action to the chlamydia heat shock protein 60 (CHSP60) and ectopic pregnancy [16]. Furthermore, seropositivity to human HSP60 decreases the chance for ectopic gestation in individuals with previous chlamydial infection [17], along with the advancement of chlamydia-associated tubal infertility [18].

Chlamydial heat shock protein is a homolog of the groEL family of heat shock proteins $[19,20]$. This family of proteins is highly conserved among both eukaryotes and prokaryotes $[21,22]$. It has been recommended that antibodies versus conserved epitopes on CHSP60 might cross respond with those of hHSP60 and initiate an autoimmune inflammatory response [23-27]. 
Table 1. Summary of individuals included in this study

\begin{tabular}{ccc}
\hline SR No & Pathology & Sample size $(\mathbf{n}=\mathbf{8 2})$ \\
\hline 1 & Tubal infertility & Age $=34.2 \pm 2.4$ years, $(\mathrm{n}=18)$ \\
\hline 2 & Non tubal infertility & Age $=32 \pm 5$ years, $(\mathrm{n}=64)$ \\
\hline I & Associated with: & 14 \\
\hline II & Male oriented & 16 \\
\hline III & Ovulatory Dysfunction & 18 \\
\hline IV & Combined Male And Ovulatory Dysfunction & 17 \\
\hline
\end{tabular}

A research study identified serum antibodies testing to the entire C.trachomatis organism as more precise than hysterosalpingography (HSG) to predict tube-related infertility [5]. We compared chlamydia serology and antibodies accuracy versus CHSP60 in predicting infertility diagnosis related to tubal factors in a prospective study.

\section{THE AIM}

This study is aimed to investigate the effectiveness of chlamydial heat shock protein 60 (CHSP60) antibodies test and to analyze the specificity and sensitivity of CHSP60 measured by ELISA in comparison with standard chlamydial antibodies measurement with other diagnostic techniques like microimmunofluorescence (MIF) in the diagnosis of tubal infertility in a prospective study.

\section{MATERIALS AND METHODS}

After the suggested research study with permission approved by the Study Ethics Board at the Obstetrics and gynecology post-graduation department, Bogomolets national medical university, Kyiv, Ukraine, sample were obtained from 82 unselected females presenting for first infertility examination in the infertility center at the gynecology department, Bogomolets national medical university, Kyiv, Ukraine. All women had necessary examinations performed, consisting of basal body temperature charting, and/or mid-luteal, and/or late luteal endometrial biopsy, cervical C. trachomatis screening with ELISA or polymerase chain reaction assays. The medical diagnosis of tubal infertility made by HSG and/or laparoscopic test exposing distal tubal blockage or laparoscopic evidence of peritubular adhesions. A laparoscopic assessment was not performed if the complete reciprocatory distal tubal obstruction was diagnosed on HSG. All collected samples were assayed for immunoglobulin IgG and IgM antibody to C. trachomatis by the microimmunofluorescence (MIF) approach of Wang, also Grayston [28] utilizing detoxed Formalin-fixed primary bodies.

Sera were assessed at a dilution of 1:8 and were tittered at double dilutions to the endpoint. Chlamydia trachomatis seropositivity was defined as a MIF titer of $n$ 1:8 [29]. An ELISA utilizing recombinant CHSP60 expressed as a mixed protein with glutathione-S-transferase, as an anti- gen, was used to analyze antibodies existence to CHSP60 as described previously $[18,30]$ patient sera were diluted 1:500 in addition to incubated with recombinant antigen bound to 96-well microtiter plates. Horseradish peroxidase-conjugated goat anti-human IgG was added, and the optical density of each was well determined. All sera favorable by ELISA were confirmed by immunoblotting using recombinant CHSP60 as antigen. Sera were checked blindly and without the information of clinical diagnose.

Groups were contrasted by y 2 or Fisher's exact test. Odds ratios (OR) with $95 \%$ confidence intervals (CI) calculated probability ratios are also computed to help the diagnostic precision of both serologic tests for their ability to anticipate tubal disease as the reason for infertility the patients came for infertility assessment. The computation of possibility ratios makes it possible to compare the diagnostic importance of tests independent of infection frequency in varying populations. The ratio for positive test calculated as sensitivity/(100 - specificity). A positive possibility of 2 to 5 recommends a non-satisfactory clinical test, 5 to 10 shows a good scientific test, and $>10$ is an excellent clinical test. The ratio for the negative test was also calculated as sensitivity/(100 - specificity). The unfavorable ratio of 0.5 to 0.2 shows an unsatisfactory examination, 0.2 to 0.1 is a good clinical assessment, and value $<0.1$ shows a superb clinical assessment [31].

\section{RESULTS}

Eighty-two (82) women were included in our research, 18 with the final diagnosis of tubal disease, 2 of those with tubal-associated problems and additionally had ovulatory dysfunction, 3 with male-oriented issues, and 3 with both male-oriented issues along with ovulatory dysfunction in the development of tubal infertility. Sixty-four women with non-tubal infertility: 14 with male variable, 16 with an ovulatory disorder, 18 with combined male factor in addition to ovulatory dysfunction, and 17 with idiopathic infertility the mean age of the women with tubal infertility was ( $34.2 \pm 2.4$ years) in comparison to those with different other causes of infertility ( $32 \pm 5$ years) as shown in Table 1 .

An overall of 8 women had a history of pelvic inflammatory disease (PID), only three with tubal conditions. Consequently, 14 of 17 women with the tubal problem in our collection had no previous background of PID. 
Table 2. Simple C. trachomatis antibodies analysis by MIF screening assay to predict tubal infertility

\begin{tabular}{|c|c|c|c|c|c|c|c|c|}
\hline \multirow{3}{*}{$\begin{array}{l}\text { Tubal VS } \\
\text { non-tubal } \\
\text { infertility }\end{array}$} & \multirow{2}{*}{$\begin{array}{l}\text { Sample } \% \text { age } \\
\text { with positive } \\
\text { MIF titer to } \\
\text { C. trachomatis } \\
\text { antibodies }\end{array}$} & \multirow{2}{*}{$\begin{array}{l}\text { Calculated } \\
\text { values }\end{array}$} & \multirow{2}{*}{$\begin{array}{c}\text { MIF } \\
\begin{array}{c}\text { Sensitivity } \\
\text { for }\end{array} \\
\text { C. trachomatis } \\
\text { antibodies }\end{array}$} & \multirow{2}{*}{$\begin{array}{c}\text { MIF } \\
\text { Specificity } \\
\text { for }\end{array}$} & \multicolumn{2}{|c|}{ Prediction value } & \multicolumn{2}{|c|}{ Probability ratio } \\
\hline & & & & & positive & negative & Favorable & unfavorable \\
\hline & $\begin{array}{l}\text { 1. Tubal } \\
12 \text { of } 18(67 \%) \\
\text { 2. non-tubal } \\
31 \text { of } 64(48 \%)\end{array}$ & $\begin{array}{c}\mathrm{P}=0.3 \\
\mathrm{OR}=2.2 \\
95 \% \mathrm{Cl}=0.71 \\
\text { to } 8.01\end{array}$ & $65 \%$ & $58 \%$ & $29 \%$ & $88 \%$ & 1.15 & 0.71 \\
\hline
\end{tabular}

$\mathrm{P}=$ power factor alpha, $\mathrm{OR}=0 \mathrm{dds}$ ratio, $\mathrm{Cl}=$ confidence interval, $\mathrm{C}$. trachomatus=Chlamydial trachomatis

Table 3. CHSP60 antibodies measurement (nonspecifically) by ELISA in all the individuals with the tubal and non-tubal cause of infertility

\begin{tabular}{|c|c|c|c|c|c|}
\hline \multirow{2}{*}{$\begin{array}{l}\text { Tubal VS non } \\
\text { tubal infertility }\end{array}$} & $\begin{array}{l}\text { Sample \% age positive to } \\
\text { CHSP60 antibodies by ELISA }\end{array}$ & Calculated values & $\begin{array}{c}\text { CHSP60 } \\
\text { antibodies } \\
\text { testing } \\
\text { Sensitivity }\end{array}$ & $\begin{array}{c}\text { CHSP60 } \\
\text { antibodies } \\
\text { testing } \\
\text { specificity }\end{array}$ & $\begin{array}{l}\text { Probability } \\
\text { ratio }\end{array}$ \\
\hline & $\begin{array}{c}\text { 1.Tubal infertility } \\
8 \text { individuals from } 18 \text { (45\%) } \\
\text { 2.nontubal infertility } \\
6 \text { individuals from 64(9\%) }\end{array}$ & $\begin{array}{c}\mathrm{P}=0.004 \\
\mathrm{OR}=9.3 \\
95 \% \mathrm{Cl}=2.1 \text { to } 43.2 \\
\text { Power }=1.002 \text { for } \mathrm{n}=0.05\end{array}$ & $44 \%$ & $93 \%$ & 6.1 \\
\hline
\end{tabular}

$\mathrm{P}=$ power factor alpha, $\mathrm{OR}=0 \mathrm{dds}$ ratio, $\mathrm{Cl}=$ confidence interval, $\mathrm{CHSP} 60=$ chlamydial heat shock proteins, $E$ LLSA=enzyme linked immunosorbent assay

Table 4. CHSP60 Antibodies measurement specifically in individuals with tubal infertility and with positive MIF titer in comparison with non-tubal infertility or negative MIF titer

\begin{tabular}{|c|c|c|c|c|c|c|c|}
\hline \multirow{3}{*}{$\begin{array}{l}\text { Tubal VS non } \\
\text { tubal infertility }\end{array}$} & \multirow{2}{*}{$\begin{array}{c}\text { Sample \% } \\
\text { age positive } \\
\text { to CHSP60 } \\
\text { antibodies by } \\
\text { ELISA }\end{array}$} & \multirow{2}{*}{$\begin{array}{c}\text { Calculated } \\
\text { values }\end{array}$} & \multirow{2}{*}{$\begin{array}{c}\text { CHSP60 } \\
\text { antibodies } \\
\text { testing Sensitivity } \\
\text { for C. trachomatis }\end{array}$} & \multirow{2}{*}{$\begin{array}{c}\text { CHSP60 } \\
\text { antibodies } \\
\text { testing } \\
\text { specificity for } \\
\text { C. trachomatis }\end{array}$} & \multicolumn{2}{|c|}{ Prediction value } & \multirow{2}{*}{$\begin{array}{l}\text { Probability } \\
\text { ratio }\end{array}$} \\
\hline & & & & & positive & negative & \\
\hline & $\begin{array}{c}\text { 1. tubal } \\
8 \text { of } 12(67 \%) \\
\text { 2. non-tubal } \\
7 \text { of } 70(10 \%)\end{array}$ & $\begin{array}{c}\mathrm{P}=0.0000412 \\
\mathrm{OR}=31.02 \\
95 \% \mathrm{Cl}=7 \text { to } \\
220\end{array}$ & $70 \%$ & $93 \%$ & $58 \%$ & $86 \%$ & 10 \\
\hline
\end{tabular}

$\mathrm{P}=$ power factor alpha, $\mathrm{OR}=0 \mathrm{dds}$ ratio, $\mathrm{Cl}=$ confidence interval, $\mathrm{C}$. trachomatus=Chlamydial trachomatis, $\mathrm{CHSP} 60=$ chlamydial heat shock proteins

Thirteen individuals were located to have endometriosis at the time of laparoscopy, and 10 of these women without any ovaries or tubes related problem. Eight women had a prior background of ectopic pregnancy, and likewise, three of these females have normal tubes at laparoscopy after the resolution of the ectopic gestation (treated with methotrexate or direct salpingostomy). The remainder of our selected individuals diagnosed infertility with male issues or related to ovulatory aspects. A positive MIF titer in 12 of $18(67 \%)$ women with the tubal issue and 31 of 64 $(48 \%)$ with various other causes of infertility $(\mathrm{P}=0.3, \mathrm{OR}=$ $2.2,95 \% \mathrm{CI}=0.71$ to 8.01$)$. Hence, screening assessment for tubal conditions, MIF has a sensitivity of $65 \%$ and specificity of $58 \%$, with a positive prediction of $29 \%$ and the negative prediction of $88 \%$. Calculation of probability ratio revealed that MIF screening for $C$. trachomatis antibodies is not a helpful medical test for the prediction of the tubal problem in the individual with infertility (favorable possibility proportion $=1.51$ as well as unfavorable chance ratio $=0.7$ ), as shown in table 2 .
The CHSP60 antibodies found in 8 of 18 (45\%) women with the tubal problem in addition to 6 of $64(9 \%)$ women with other causes of infertility, power factor alpha $\alpha \mathrm{P} .=0.004$, $\mathrm{OR}=9.3,95 \% \mathrm{CI}=2.1$ to 43.2 , probability ratio $=6.1$, power $=$ 1.002 for $\mathrm{n}=0.05$ ). Consequently, as an indicator of tubal infertility, CHSP60 antibody testing has a sensitivity level of $44 \%$ and specificity of $93 \%$, as shown in table 3 .

For diagnosis of Chlamydial linked tubal problems (specified as the tubal condition with a positive MIF titer), the CHSP60 test performed in 8 of 12 (67\%) patients with tubal disease in addition to 7 of $70(10 \%)$ females with other causes of infertility or with a negative MIF titer (P. $=0.0000412, \mathrm{OR}=31.02 \%, \mathrm{CI}=7$ to 220 ). Therefore, the level of sensitivity of the CHSP60 assay for discovering C. trachomatis linked tubal disease is $70 \%$, along with its 93\% specificity. The positive value of prediction for the CHSP60 assessment for the medical diagnosis of tubal infertility is $58 \%$ as well as the negative value of prediction is $86 \%$, as shown in Table 4 . A person with the tubal condition is 6.1 times more likely than women without 


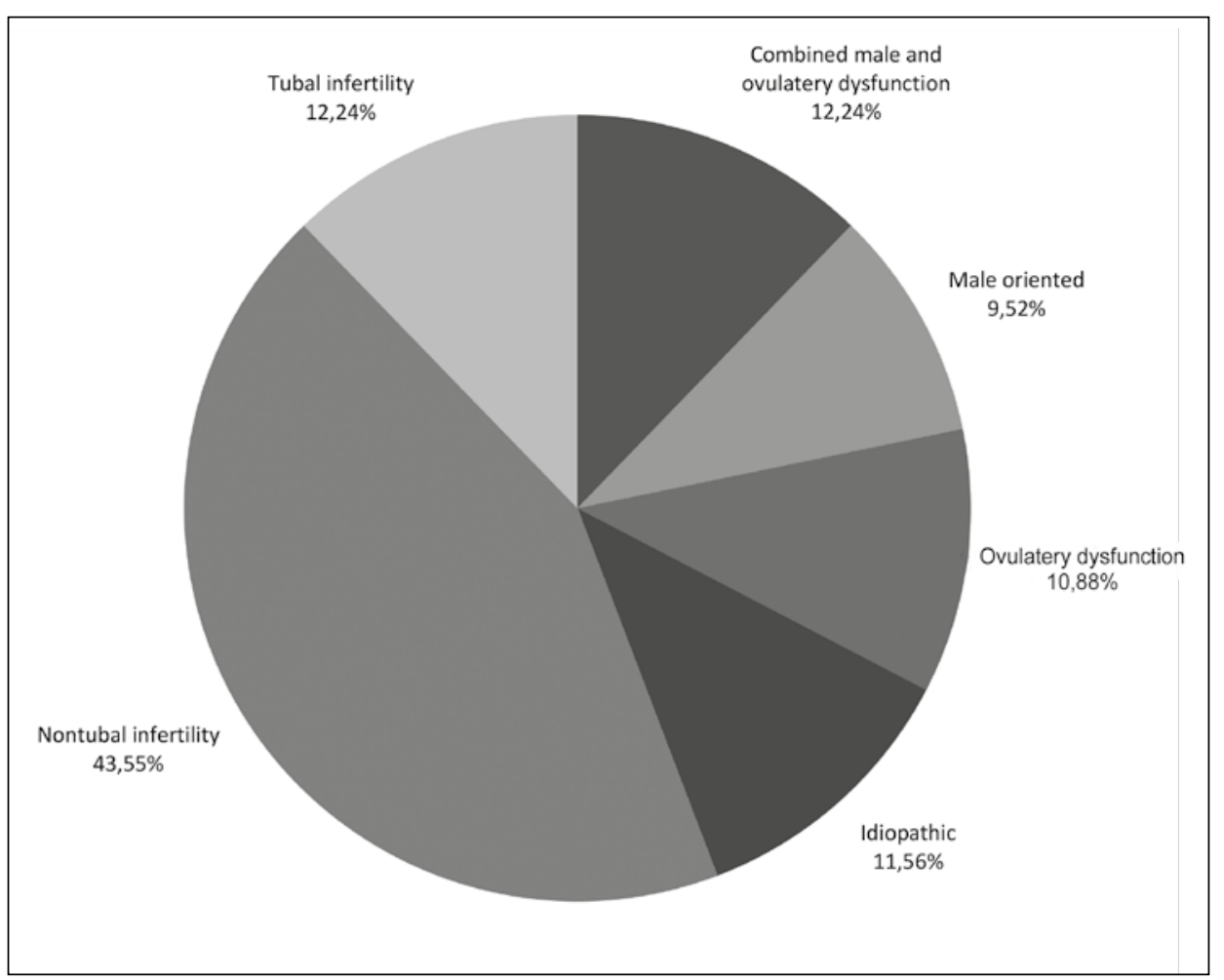

Fig. 1. Causes of infertility in a sample of the population. tubal problems to have antibodies to CHSP60 (positive probability proportion).

The structure of tubal and non-tubal causes of infertility in the population sample selected for this study is presented in Figure 1.

\section{DISCUSSION}

\section{CLINICAL FINDINGS}

The determination of CHSP60 antibodies was a more accurate and particular technique to identify tubal infertility associated with c. trachomatis infection. The MIF was a more sensitive but less specific diagnostic method.

It has been recommended that $\mathrm{C}$ trachomatis anti- body screening might be valuable as a testing parameter in diagnosis for tubes related infertility [32]. As a forecaster of tubal condition, we located that the MIF for $C$. trachomatis test has limited specificity of merely $58 \%$ and a level of sensitivity of $65 \%$ for anticipating tubal condition in our center population.

The negative and positive ratios of 1.51 and 0.71 , respectively, indicate the low sensitivity of MIF for diagnosis of tubes associated problems. The seroprevalence of C. trachomatis in most grown-up populations is $40 \%$ to $60 \%$ [33]. The MIF assessment permits a useful and more specific discovery of antibodies against different chlamydial strains [34]. Furthermore, Dabekausen et al.s [5] interpretation of tubal disease consisted of tubo-peritoneal adhesion in addition to independent tubal pathology seen at laparoscopy. In contrast, in our collection, we specified tubal condition as the direct exposure of bilateral distal tubal clog or considerable peri tubal adhesion.
The degree of sensitivity of this evaluation for finding tubal condition is negative; the $92 \%$ specificity of this test for finding tubal condition makes it an important assay. The favorable probability proportion of CHSP 60 antibodies screening found out the presence of the tubal condition in an unselected population of individuals providing for infertility was 6.1 , making it an outstanding examination for predicting tubal presence associated infertility. The CHSP60 antibodies screening will help reveal the tubal damages resulting from $C$. trachomatis infections and help differentiate with other infertility causes.

Brunham et al. [23] previously reported that 19 of 21 (91\%) females with ectopic pregnancy along with seropositive for C. trachomatis had antibodies to CHSP60. Three of these four women had CHSP60 antibodies (75\%) Just 4 of these seven females had an apparent tubal problem.

\section{STRENGTHS AND LIMITATIONS}

This study's strengths are selecting individuals, especially those with the infertility issue associated with tubal factors and full patient background (e.g., age, BMI, ethnic background, essential language, gravidity and parity, other comorbidities, previous infections, present medications). This research study is a suitable rep evaluation for tubal infertility risks evaluation in the Kyiv, Ukraine population and also contributes to literary works on the prospective impact on the female with infertility connected with fallopian tubes.

Limitations of the study included the prospective case-control nature of the study, restricting the data collection. The sample size was also very limited as only those individuals were included whose infertility problem was explicitly associated with fallopian tubes. 
The data was collected only from three institutes. There are regularly institutional propensities in providing medical diagnosis and treatment to women, and duplicating this research study with multiple research studies would undoubtedly reinforce our results' generalizability.

Women with tubal infertility, age less than 40 years or more than 25 years, with ovulatory dysfunction, endometriosis, ectopic pregnancy, and women with routine gynecological check-up were included.

Females with a previous history of autoimmunity, oncology, or hypersensitivity were excluded.

\section{RESEARCH IMPLICATION}

It is not well understood that CHSP60 antibodies in serum itself a reason for tubal infertility, or it sets off the activation of a few other chemical cascades in the body that results in this pathology's growth. Further immunochemical studies need to be done on this parameter. Given the exploratory nature of the results, we await verification of our research from future research studies. We also hope to discover associations amongst tubal infertility and various other kinds of heat shock proteins (HSP) i. e HSP 10, 70, 90, 110 , and the decision of specific criterion to diagnose the linked etiology.

\section{CLINICAL IMPLICATION}

Among the essential factors for screening for chlamydia, unlike other sexually transmitted disorders as a cause of the tubal problem, interestingly infertility is the significant outcome of genital chlamydia infections in women, and mostly these infections are asymptomatic. Non-treated and ignored infections can spread into the upper genital system and likewise trigger PID (pelvic inflammatory disease) with resultant ectopic gestation as well as tubal occlusion and other complications. Numerous study studies have shown that most women with the tubal cause of infertility did not mind a history of chlamydia infection [4]. These examinations would undoubtedly be a fast and definite helpful approach for establishing the diagnose in these women without various other unwanted and expensive interventive treatment and diagnostic measures.

\section{OUTCOME}

The performance of the CHSP60 antibodies assessment depends upon its high specificity (92\%) and good positive ratio (6.1) for the presence of tubal infertility. The negative MIF analysis has an excellent (85\%) negative value of prediction that makes it useful alone in diagnosing tube-related infertility.

A positive MIF assay combined with CHSP60 antibody screening generates an extraordinary $C$. trachomatis-linked tubal infertility (good possibility ratio $=10$ ). The CHSP60 antibodies evaluation and MIF testing should exist as an analysis tool as part of the first infertility examination.
The women with a positive CHSP60 antibody assay might consider moving into IVF-ET treatment instead of finding extra interceptive and expensive screening examination, mainly IVF-ET seems specifically reliable in treating tubal-associated infertile females that have antibodies to the CHSP60 [34].

\section{CONCLUSIONS}

The Chlamydia Trachomatis infection is one of the significant risk elements for the development of tubal infertility. The measurement of CHSP60 antibodies by ELISA in serum samples is a particular extra parameter to detect tubal infertility related to chlamydial trachomatis infection instead of primary antibody C. Trachomatus as well as using a less specific microimmunofluorescence (MIF) strategy. The use of both methods together at the preliminary diagnostic evaluation of women may help provide the prompt diagnosis as MIF has a lot more sensitivity and CHSP60 antibodies by ELISA is extra particularly specific for medical diagnosis of Chlamydia Trachomatis linked tubal infertility.

\section{REFERENCES}

1. Westrom L., Chlamydia and its effect on reproduction. Journal of the British Fertility Society. 1996; 1(1): 23.

2. Coppus $S$. et al., Chlamydia trachomatis lgG seropositivity is associated with lower natural conception rates in ovulatory subfertile women without visible tubal pathology. Human Reproduction. 2011; 26(11): 3061-3067.

3. Linhares I.M., Witkin S.S., Immunopathogenic consequences of Chlamydia trachomatis $60 \mathrm{kDa}$ heat shock protein expression in the female reproductive tract. Cell Stress and Chaperones. 2010; 15(5): 467-473.

4. Cates J.W., Wasserheit J.N., Genital chlamydial infections: epidemiology and reproductive sequelae. American journal of obstetrics and gynecology. 1991; 164(6): 1771-1781.

5. Dabekausen Y.A. et al., Chlamydia trachomatis antibody testing is more accurate than hysterosalpingography in predicting tubal factor infertility. Fertility and sterility. 1994; 61(5): 833-837.

6. Tsevat D.G. et al., Sexually transmitted diseases and infertility. American journal of obstetrics and gynecology. 2017; 216(1): 1-9.

7. Dalal R., Infection and Infertility, in Genital Infections and Infertility. Intech0pen, 2016.

8. Schuchardt L., Rupp J., Chlamydia trachomatis as the cause of infectious infertility: acute, repetitive or persistent long-term infection?, in Biology of Chlamydia. 2016; Springer: 159-182.

9. MullerV. et al., Association between anti-chlamydial immunity and IVF outcome. Gynecological Endocrinology. 2015; 31(sup1): 69-73.

10. Hoenderboom B.M. et al., Relation between Chlamydia trachomatis infection and pelvic inflammatory disease, ectopic pregnancy and tubal factor infertility in a Dutch cohort of women previously tested for chlamydia in a chlamydia screening trial. Sexually transmitted infections. 2019; 95(4): 300-306.

11. Den Heijer C.D. et al., Chlamydia trachomatis and the risk of pelvic inflammatory disease, ectopic pregnancy, and female infertility: a retrospective cohort study among primary care patients. Clinical Infectious Diseases. 2019; 69(9): 1517-1525. 
12. Cheong H.C. et al., CPAF, HSP60 and MOMP antigens elicit proinflammatory cytokines production in the peripheral blood mononuclear cells from genital Chlamydia trachomatis-infected patients. Immunobiology. 2019; 224(1): 34-41.

13. Nsonwu-Anyanwu A.C. et al., Female reproductive hormones and biomarkers of oxidative stress in genital chlamydia infection in tubal factor infertility. Journal of reproduction \& infertility. 2015; 16(2): 82.

14. Grayston J.T. et al., Importance of reinfection in the pathogenesis of trachoma. Reviews of infectious diseases. 1985; 7(6): 717-725.

15. Patton D.L. et al., Distal tubal obstruction induced by repeated Chlamydia trachomatis salpingeal infections in pig-tailed macaques. Journal of Infectious Diseases. 1987; 155(6): 1292-1299.

16. Hoenderboom B. et al., The Netherlands Chlamydia cohort study (NECCST) protocol to assess the risk of late complications following Chlamydia trachomatis infection in women. BMC Infectious Diseases. 2017; 17(1): 1-9.

17. Ozyurek E.S. et al., Seropositivity for the human heat shock protein (Hsp) 60 accompanying seropositivity for Chlamydia trachomatis is less prevalent among tubal ectopic pregnancy cases than individuals with normal reproductive history. European Journal of Obstetrics \& Gynecology and Reproductive Biology. 2018; 223: 119-122.

18. Toye B. et al., Association between antibody to the chlamydial heatshock protein and tubal infertility. Journal of Infectious Diseases. 1993; 168(5): 1236-1240.

19. Morrison R.P. et al., The Chlamydia trachomatis hyp operon is homologous to the groE stress response operon of Escherichia coli. Infection and immunity. 1990; 58(8): 2701-2705.

20. Cerrone M., Ma J., Stephens R., Cloning and sequence of the gene for heat shock protein 60 from (hlamydia trachomatis and immunological reactivity of the protein. Infection and immunity. 1991; 59(1): 79-90.

21. Kaufmann S.H., Heat shock proteins and the immune response. Immunology today. 1990; 11: 129-136.

22. Res P., Thole J., deVries RRP. Heat shock proteins in immunopathology. Cu w Opin Immunol. 1991; 3: 924-9.

23. Brunham R. et al., Chlamydia trachomatis-associated ectopic pregnancy: serologic and histologic correlates. Journal of Infectious Diseases. 1992; 165(6): 1076-1081.

24. Arno J.N. et al., Serologic responses of infertile women to the $60-\mathrm{kd}$ chlamydial heat shock protein (hsp60). Fertility and sterility. 1995; 64(4): 730-735.

25. Witkin S.S. et al., Cell-mediated immune response to the recombinant 57-kDa heat-shock protein of Chlamydia trachomatis in women with salpingitis. Journal of Infectious Diseases. 1993; 167(6): 1379-1383.

26. Witkin S.S. et al., Proliferative response to conserved epitopes of the Chlamydia trachomatis and human 60-kilodalton heat-shock proteins by lymphocytes from women with salpingitis. American journal of obstetrics and gynecology. 1994; 171(2): 455-460.

27. Yi Y., Zhong G., Brunham R.C., Continuous B-cell epitopes in Chlamydia trachomatis heat shock protein 60. Infection and immunity. 1993;61(3): $1117-1120$.
28. Wang S.-P., Grayston J.T., Human serology in Chlamydia trachomatis infection with microimmunofluorescence. Journal of Infectious Diseases. 1974; 130(4): 388-397.

29. Newhall W., Batteiger B, Jones R., Analysis of the human serological response to proteins of Chlamydia trachomatis. Infection and Immunity. 1982; 38(3): 1181-1189.

30. Toye B. et al., Immunologic characterization of a cloned fragment containing the species-specific epitope from the major outer membrane protein of Chlamydia trachomatis. Infection and immunity. 1990; 58(12): 3909-3913.

31. Collins J., Male infertility: the interpretation of the diagnostic assessment. 1989 The Year Book of Infertility. 1989; 45.

32. Moore D. et al., Increased frequency of serum antibodies to Chlamydia trachomatis in infertility due to distal tubal disease. The Lancet.1982; 320(8298): 574-577.

33. Grayston J.T., Infections caused by Chlamydia pneumoniae strain TWAR. Clinical Infectious Diseases. 1992; 15(5): 757-761.

34. Claman P. et al., Does serologic evidence of remote Chlamydia trachomatis infection and its heat shock protein (CHSP 60) affect in vitro fertilization-embryo transfer outcome? Fertility and sterility. 1996; 65(1): 146-149.

\section{ORCID and contributionship:}

Vladyslav Berestoviy: 0000-0002-5880-770X $X^{A, C, D}$

Inna Sokol: 0000-0001-6667-1913 ${ }^{B, C, F}$

Ahmad Mahmood: 0000-0002-6642-2324 ${ }^{A, B, D}$

Valentyna G. Ginzburg: 0000-0001-9669-02189

Dmytro Govsieiev: 0000-0001-9669-0218

\section{Conflict of interest:}

The Authors declare no conflict of interest.

\section{CORRESPONDING AUTHOR Vladyslav 0. Berestoviy}

Obstetrics and gynecology post-graduation department Bogomolets National Medical University Lobanovskoho Avenue 2, 03037 Kyiv, Ukraine

tel: +380970037773

e-mail:vladberestovoy@gmail.com

Received: 09.09 .2020

Accepted: 04.01.2021

A - Work concept and design, B - Data collection and analysis, C - Responsibility for statistical analysis, D-Writing the article, $\mathbf{E}$ - Critical review, $\mathbf{F}$ - Final approval of the article 